\title{
AS ILUSÕES (E AS TAREFAS) DA DEMOCRACIA E DA CIDADANIA Possíveis Contribuições da Educação Escolar
}

\author{
lael de Souza ${ }^{1}$ \\ Evaldo Piolli²
}

\begin{abstract}
RESUMO
Demonstrar os limites da democracia e cidadania burguesas e, por outro lado, como podem servir de meio (jamais sendo um fim) para a radicalização das lutas sociais em prol da emancipação econômica, proporcionando as condições para a maturação da emancipação humana e, como, ao longo desse processo de transformação social radical, a educação escolar pode fazer sua contribuição; essas são questões cruciais que, cada vez mais, devem ser refletidas, debatidas e propagadas a fim de que possamos, efetivamente, fortalecer a perspectiva do trabalho contra a do capital.
\end{abstract}

Palavras-chave: Democracia. Cidadania. Educação escolar.

\section{THE ILLUSIONS (AND TASKS) OF DEMOCRACY AND CITIZENSHIP: POSSIBLE CONTRIBUTIONS OF SCHOOL EDUCATION}

\begin{abstract}
Demonstrate the limits of democracy and bourgeois citizenship and, moreover, how can they serve as a medium (never being an end ) to the radicalization of social struggles toward economic emancipation, providing the conditions for the maturation of human emancipation and how, throughout this process of radical social transformation, school education can make its contribution. These are crucial questions that, increasingly, must be reflected, debated and propagated so that we can effectively strengthen the prospect of labor against capital.
\end{abstract}

Keywords: Democracy. Citizenship. School education.

RECEBIDO EM: 20/8/2017

ACEITO EM: $7 / 8 / 2018$

\footnotetext{
${ }^{1}$ Mestre em Ciências Sociais pela Unesp - Marília. Doutoranda em Educação pela Unicamp - SP. Professora efetiva da Universidade Federal do Piauí (Ufpi). iaeldeo@gmail.com

2 Doutor em Educação pela Unicamp - São Paulo. Professor efetivo do Departamento de Políticas, Administração e Sistemas Educacionais (Depase) da Faculdade de Educação da Unicamp - SP. Pesquisador do Laboratório de Gestão Educacional (Lage) e líder do Grupo de Pesquisa Trabalho, Saúde e Subjetividade (NETSS).epiolli@yahoo.com.br.
} 
Ao longo da história humana, os povos que viveram sob regimes de exploração e escravidão, de dominação e subsunção, tenham sido eles monárquicos, ditatoriais, ou variações do gênero, ansiaram, sublevando-se em lutas sangrentas e encarniçadas, por liberdade, igualdade e justiça, para fazer germinar um "novo mundo" ou um "mundo novo", onde todos os homens tivessem voz e vez, tendo autonomia sobre si mesmos, incluindo seu próprio corpo. Nesse contexto, democracia e cidadania tornam-se a tradução e a máxima pelas quais são sacrificadas milhares de vidas.

Compreendemos, assim, porque, após períodos ditatoriais, ou de regimes monárquicos, marcadamente centralizados, totalitários, o desejo das massas é expresso por meio das lutas, também massivas, para garantir os direitos civis, políticos e sociais, principalmente os dois primeiros, cerceados ou então parca e minguadamente contemplados em tempos tão obscuros, repressivos, opressivos, temerosos e duros, de ampliado e intensificado controle sobre o social.

Após esses períodos histórico-sociais, acreditamos que uma grande comoção, um amálgama de sensações e sentimentos, atravessam as massas, sendo um dos fatores, ainda que não o único nem o principal, responsável pelo clima de expectativa e necessidade de mudanças sentido que, como um tsunami, vem à tona como uma força aparentemente incontrolável, e justamente por ser aparente é que é possível uma saída tática para manter a estratégia: mudar de forma que se mantenha o que existe, o existente; e canalizar todas as energias, todas as forças sociais provocadas e acordadas, que então respondem e ameaçam se tornar sujeitos de sua própria história para a conquista e ampliação de direitos - racional, legal, institucionalizado, legítimo -, geralmente culminando com constituições, então legitimadas, servindo para refrear os ânimos, o calor contagiante dos acontecimentos, aplacando, muito sutil e eficazmente, o movimento espontâneo das massas. Assim, espera-se que a lei realize a "mudança", capturando as forças sociais reais das massas que estão organizadas e mobilizadas nas ruas, potencialmente capazes de efetivamente fazer acontecer - e impor - a transformação, e não a mudança. O real é subsumido pelo legal e, assim, a ordem se restabelece e mantém.

Democracia e cidadania, se forem mantidas nos limites da dominação política burguesa, ou seja, nos limites do Estado de Direito Representativo-Democrático, perpetuarão a desigualdade social, a propriedade privada, a exploração do homem pelo homem e a opressão de uma classe por outra mediante o Estado capitalista, logo, um Estado de classe, cuja função é garantir a manutenção da luta de classes e não a sua erradicação, como já alertava Engels (1984). Enfim, manter-se-á a lógica da produção e reprodução da forma social capital e de seu desenvolvimento desigual e combinado.

É o que procuraremos demonstrar no presente artigo, evidenciando os limites da democracia e da cidadania, como também de que modo podem vir a contribuir enquanto meios (mediação) de radicalização da luta do trabalho contra o capital, criando as condições para a superação do sistema capitalista. Por fim, também buscaremos destacar como a educação, pontualmente a escolar, pode contribuir nesse processo de radicalização da luta pela transformação social, auxiliando no desenvolvimento das consciências, na superação de sua alienação e estranhamento, potencializando as condições 
subjetivas para a realização das transformações objetivas e das lutas a serem travadas nos diversos campos socioculturais para a efetivação da emancipação econômica no intuito de realizar a emancipação humana.

\section{AS ILUSÕES DE DEMOCRACIA E DE CIDADANIA}

Democracia, do grego demokratia, do latim, democratia, decomposta em demos = povo, distrito e kratos = domínio, poder, donde resulta a denominação poder do povo ou governo do povo (para o povo, pelo povo), contrapõe-se à ditadura, do latim, dicere = dizer, falar, contar, com ligação no Indo-Europeu deik = indicar. Dessa raiz Indo-Europeia veio também o latim digitus = dedo, e o grego deiknynai $=$ provar. Destarte, a gíria "dica", significando informação ou indicação, apresenta-se extremamente adequada, posto que deriva de indicar, que vem de in-, "em", mais dicare = proclamar, asseverar, parente próximo de dicere. Daí em diante, muitos são os derivados, como ditar = pronunciar um texto em voz alta, mas também quer dizer impor ideias ou condutas, prescrever, determinar. E assim temos: ditador, ditadura.

A primeira corresponde a um governo com participação popular na vida política, econômica e cultural da sociedade. Resguarda a liberdade individual e os direitos humanos fundamentais: 1) civis: direitos fundamentais à vida, à liberdade, à propriedade e à igualdade perante a lei. Sua base lapidar é a liberdade individual; 2) políticos: reportam à participação do "cidadão" no governo da sociedade. Em geral, se refere ao direito do voto, mas também inclui a capacidade de fazer demonstrações políticas, de organizar partidos. Sua essência é a ideia de autogoverno; 3) sociais: garante a participação na riqueza coletiva. Eles incluem o direito à educação, ao trabalho, ao salário justo, à saúde, à aposentadoria. Os direitos sociais permitem às sociedades politicamente organizadas reduzir os excessos de desigualdade produzidos pelo capitalismo e garantir um mínimo de bem-estar para todos. A ideia central em que se baseiam é a da justiça social (CARVALHO, 2002). Vemos, portanto, que "direitos" e "liberdade individual" são dois elementos nodais na democracia.

Já o regime ditatorial, e suas variantes (monarquia absoluta, por exemplo), impõe o arbítrio de um indivíduo, que está acima de todos os demais, tendo poder absoluto e incontestável, podendo perseguir, prender, oprimir, reprimir aqueles que possam contestá-lo, ameaçando seu poder. Participação popular, em qualquer instância (política, econômica, sociocultural) é vetada. Os direitos políticos e civis são os mais atingidos em tempos de ditadura e, invariavelmente, atrofiam. Esse aspecto nos auxilia na compreensão das razões da efervescência das massas quando da mudança na conjuntura histórico-social e das forças circunstanciais que entreabrem um período de "reabertura democrática", aumentando o anseio por direitos civis e políticos.

A história parece demonstrar que a democracia e sua inseparável companheira, a cidadania, são, concomitantemente, conquistas e formas de frear o alvorecer da consciência das classes oprimidas, dominadas e exploradas, pois, ao garantir pela força da lei as liberdades e direitos, faz arrefecer a energia não reformista, mas sim revolucionária, das massas, que novamente são dócil, obediente e disciplinarmente aprisionadas pelas normas, regras, resoluções, estatutos, parágrafos, artigos, atos, decretos do braço jurídico-político do capital: o Estado de Direito. 
Vejamos a origem e natureza desse brilhante e ludibriante par. Nosso ponto de partida é John Locke (2002), pai do liberalismo econômico moderno e um dos teóricos do contratualismo, um dos pilares de sustentação da forma social capital, uma vez que a valorização do valor e a acumulação capitalista são viabilizadas pela compra e venda da força de trabalho; em outras palavras, pela exploração da força de trabalho, quando as desigualdades reais e sociais entre trabalhador (não possuidor dos meios de produção) e capitalista (possuidor dos meios de produção) - que define o lugar por eles ocupado na divisão técnico-científica-hierárquica-social do trabalho e delimita suas condições materiais de existência e suas formas de reprodução social - são suspensas, pois, como contratantes, ambos são proprietários (de mercadorias), livres (escolhem de quem comprar, para quem vender) e iguais (perante a lei), por isso podem dispor de si e de seus meios/bens conforme melhor lhe aprouver, acordando circunstâncias e condições.

Os contratualistas operam uma inversão histórica. Para eles, os indivíduos antecedem a sociedade, dado que esta última resulta do contrato social firmado entre os mesmos ainda no estado de natureza (um estado hipotético, racional) para assegurar o direito natural à vida (busca da paz e segurança), à propriedade (acumular riquezas) e à liberdade (buscar seu progresso e desenvolvimento, sua realização pessoal), embora o essencial seja a propriedade, que no estado de natureza encontra-se à mercê de invasões alheias que ameaçam tomar indevidamente o que foi produzido pelo trabalho de determinado indivíduo, pois, por intermédio do trabalho, ele legitimou a posse do que antes era comum a todos, considerando que aperfeiçoou e fez progredir e desenvolver a terra e tudo o que era ofertado pela natureza, produzindo e retirando, com seu trabaIho, seus frutos (agricultura, pecuária, extração vegetal, mineral, etc.).

O maior e principal objetivo, portanto, dos homens se reunirem em comunidade, aceitando um governo comum, é a preservação da propriedade. De fato, no estado de natureza faltam muitas condições para tanto (LOCKE, 2002, p. 92).

Vemos, aqui, a "típica projeção ideológica do individualismo burguês" (GRUPPI, 2001, p. 16). A sociedade nasce para salvaguardar os interesses particulares dos indivíduos, indo na contramão do processo histórico-social real, o qual demonstra, por intermédio dos fatos, que o ser se funda como ser social em relação colaborativa com os demais seres sociais, pela mediação do trabalho, o medius, entre os homens e a natureza e dos homens entre si, criando, assim, as sociabilidades (organizações sociais, modos de vida) humanas. Contrariamente, no raciocínio liberal a sociedade civil e o governo civil, portanto o Estado de Direito, nascem para tutelar a propriedade privada.

Outro ponto que merece destaque é a afirmação da igualdade essencial (natural) entre os homens. Num primeiro momento, ela foi utilizada pela burguesia na sua luta contra o antigo regime, derrubando todas as formas de privilégio do clero e da nobreza. Nesse momento, portanto, ela tem um caráter revolucionário, de ruptura efetiva com o existente. O perigo, porém, estava em estender essa ideia ao novo contexto da sociedade capitalista, em que as desigualdades entre trabalhadores e capitalistas não poderiam, jamais, ser erradicadas. Algumas mudanças precisariam ser operadas, e assim se procedeu. 
Primeira questão: Como justificar a desigualdade entre os homens se, no transcorrer do processo revolucionário burguês, eles foram racional e comprovadamente confirmados como essencial e naturalmente iguais? Novamente, a solução era dada pelo liberalismo econômico e pelos contratualistas. Se no estado de natureza os homens são livres, iguais e independentes, cada um pode, individualmente, usar seu arbítrio e buscar a sua realização pessoal. O único limite é a preservação da vida, a própria e a de outrem.

Na busca do progresso, desenvolvimento e êxito próprios, os indivíduos, mediante seu trabalho (entendido como esforço particular e também como propriedade em cada e de cada homem), se apropriam privadamente daquilo que antes era bem comum (público). O limite dessa apropriação é o usufruto, de modo que os indivíduos não saiam tomando indevidamente tudo aquilo que Ihes aprouver. Afinal, "Deus nada criou para o homem desperdiçar e destruir" (LOCKE, 2002, p. 40).

Apesar disso, a propriedade do trabalho provoca e ao mesmo tempo justifica a divisão desigual da propriedade comunal. É assim que a liberdade é, em sua origem e natureza, entendida como liberdade do proprietário, tanto que o governo civil, a sociedade civil, é a garantia de que os indivíduos consigam viver sem molestar uns aos outros em razão da existência formal, jurídica (o surgimento do Estado de Direito) e da garantia de usufruto da propriedade, impossível no estado de natureza, posto que a propriedade encontrava-se, ali, sujeita a invasões por parte dos outros, gerando o estado de guerra, representado por uma "condição de inimizade e destruição" (LOCKE, 2002, p. 31), mesmo que no estado de natureza, para Locke, naturalmente imperasse a paz, pois os indivíduos buscam a paz e a segurança como parte de preservação da vida e do direito natural à vida e à lei de natureza, que pode ser executada pelos indivíduos, permitindo, legitimamente, que cada um defenda sua vida do ataque ou ameaça realizados por outro, castigando-o ou retirando-Ihe a vida, evitando, assim, que cometa o mesmo ato contra um outro alguém.

Para impedir aos homens que invadam os direitos alheios e que mutuamente se molestem, e para que seja observada a lei de natureza, que importa na paz e na preservação de toda a Humanidade, faz-se naquele estado, a execução da lei da natureza nas mãos de todos os homens (...) (LOCKE, 2002, p. 25).

Antes de continuarmos, vale a pena ressaltar que é justamente o fato da ausência de imparcialidade e da prevalência da parcialidade inerente aos indivíduos em seus julgamentos em relação aos demais no estado de natureza - seja por amizade, benevolência ou por vingança e mesmo inclinação para o mal em relação aos que não lhe são benquistos, nem fazem parte do rol de seus amigos ou parentes - que impõe como necessária - juntamente à necessidade de garantir e preservar a propriedade adquirida no estado de natureza, possibilitando acumular ainda mais riquezas -, a reunião dos homens em sociedade, estabelecendo um pacto social (o contrato social) do qual resulta o Estado de Direito, o governo civil, a sociedade civil - política, legal e juridicamente organizada em direitos e deveres -, consensualmente legitimada, uma vez que os indivíduos transferem seu poder de executar a lei de natureza à comunidade representada em algumas pessoas previamente escolhidas por esses mesmos indivíduos por meio do voto (transformado, mais tarde, em sufrágio universal), cuja autoridade é respaldada 
pela força da lei (poder legislativo), que iguala todos os homens, além de pressupor o conhecimento, a aceitação e a acreditação, por toda a sociedade, das normas e regras escritas, transformadas em lei, garantindo, assim, a paz, a ordem e a segurança para a preservação da propriedade pessoal, privada e, particular.

Retomando, podemos ressaltar que a propriedade, existente desde o estado de natureza, evidencia que a liberdade de cada um em buscar seu progresso, desenvolvimento e realização individual mediante a propriedade particular do trabalho, justifica a desigualdade social entre os homens, de maneira que "para o liberal, há liberdade na medida em que se leve em consideração a desigualdade entre proprietários e nãoproprietários, sendo que a igualdade (econômica) mataria a liberdade" (GRUPPI, 2001, p. 21). Decorre daí a igualdade, necessariamente, de poder e dever ser apenas jurídica e formal, cindindo o homem em dois: o indivíduo (esfera privada) e o cidadão (esfera pública).

"Os direitos políticos ativos cabem somente aos proprietários" (GRUPPI, 2001, p. 18). São eles os indivíduos independentes, que "podem exprimir uma opinião política, decidir da política do Estado, não (dependendo) de outros" (p. 18). Eis a relação inequívoca e indivisível entre propriedade e liberdade: só é livre quem for proprietário. A máxima diz que "todos são iguais perante a lei", todavia "a lei sobrepõe-se à soberania do povo", dado que "sempre correspondem ao direito natural (de propriedade e liberdade)" (p. 19). Os ditos "direitos de liberdade são gozados principalmente na vida particular, pois são direitos de iniciativa econômica" (p. 25). Logo, a liberdade identifica-se com desigualdade e não com igualdade, e, incontestavelmente, a exige. Afinal, não sendo um homem integral, mas cindido, a igualdade refere-se, apenas, à semelhança entre os indivíduos como seres humanos e não como cidadãos. Assim, alguns são mais iguais do que outros perante a lei.

O direito do homem à liberdade não se baseia na união do homem com o homem, mas, pelo contrário, na separação do homem em relação a seu semelhante. A liberdade é o direito a esta dissociação, o direito do indivíduo delimitado, limitado a si mesmo. (...) (A sociedade capitalista, burguesa, é a) sociedade que faz com que todo homem encontre noutros homens não a realização de sua liberdade, mas, pelo contrário, a limitação desta. (...) O homem enquanto membro da sociedade burguesa é considerado como o verdadeiro homem, como homem, distinto do cidadão por se tratar do homem em sua existência sensível e individual imediata, ao passo que o homem político é apenas o homem abstrato, artificial, alegórico, moral. O homem real só é reconhecido sob a forma de indivíduo egoísta; e o homem verdadeiro, somente sob a forma do cidadão abstrato (MARX, [1989?], p. 31-32, 37 , grifos do original. O parêntese é meu).

As desigualdades reais existentes entre os "indivíduos egoístas", correspondentes às condições materiais de existência e reprodução social, são desterradas e parecem desaparecer. A igualdade jurídica separa a vida econômica da vida política (participação no governo, resumida, a bem da verdade, ao direito ao voto). A primeira dimensão corresponde, num primeiro momento, ao lugar ocupado pelos indivíduos nas relações sociais e de produção, na divisão social-técnica-hierárquica do trabalho. Como demonstra lasi (2011, p. 107), envolve vários componentes, dentre eles: a) "o lugar e o papel ocupados na estrutura produtiva e na divisão social do trabalho"; b) "a posição diante da proprie- 
dade, ou não propriedade, dos meios de produção"; c) "pela consciência que se associa ou distancia de uma posição de classe" e, por fim, d) "pela ação dessa classe nas lutas concretas no interior de uma formação social".

Ainda nessa direção, acrescenta Gruppi (2001, p. 41):

O problema é o de desencadear uma revolução econômico-social após a revolução política, a fim de estabelecer uma igualdade econômico-social, de reunificar os dois aspectos, de cidadão e de trabalhador, a fim de reconquistar a unidade do homem, que é homem também quando trabalha, isto é, em sua posição nas relações de produção e de troca. (...) (A liberdade burguesa) concebe indivíduos separados, como se eles não vivessem em sociedade. Diz Marx: é preciso sair dessa concepção da liberdade como uma função puramente individualista; é preciso compreender que muito pelo contrário, a liberdade é cooperação, solidariedade, trabalho coletivo. Enfim, é preciso passar da figura do cidadão (abstrato, alegórico, artificial, moral, formal) à do companheiro ou, se quisermos, da figura do trabalhador explorado à do produtor - como diria posteriormente Gramsci. Para reconquistar a unidade do homem é preciso superar esse dualismo, essa separação entre indivíduo e cidadão (Os parênteses são meus).

Somente com a superação da cisão entre vida pública e vida privada, entre cidadão e indivíduo, pautada na liberdade que exige a desigualdade e se funda na propriedade, é que se pode restabelecer a integralidade do homem real, do ser social. Isso, no entanto, é impensável na lógica e justificativa ideológica liberal. Como vimos, ela faz o inverso, justificando a desigualdade social como consequência da liberdade e igualdade natural dos homens no estado de natureza, que poderia gerar, pela parcialidade inerente aos indivíduos, um estado de guerra, aumentando os conflitos e as tensões ao limite do insuportável, colocando em risco a preservação da vida e da propriedade. Para salvaguardar seus interesses, a paz e a segurança, os indivíduos estabelecem, de livre vontade, um contrato social (que exige que as partes sejam iguais, livres - racionais - e proprietárias), engendrando a sociedade civil, o governo civil e o Estado de Direito.

Nesse contexto, "a desigualdade social é considerada legítima e constitutiva do mundo humano. Tratava-se, pois, não de suprimi-la, o que seria impossível, mas apenas de coibir os seus excessos" (TONET, 2012a, p. 64). Fica assim explicitado como a burguesia conseguiu justificar a desigualdade social entre os homens como algo aparentemente natural, inerente e imanente às relações humanas, como se fosse uma natureza natural e não o que, de fato, é: um produto das relações sociais construídas pelos próprios homens ao longo de sua história processual, de modo que a única natureza verdadeiramente humana é a social, isto é, aquela que é produzida pelos homens e que também os produz.

Assim,

ainda que não se falasse em cidadania, a igualdade e a liberdade naturais já punham a base para o seu desenvolvimento futuro. Neste sentido, todos os homens já eram potencialmente cidadãos. O desenvolvimento posterior, sempre complexo e contraditório, seria apenas a concretização daquilo que já estava posto, como possibilidade, desde o início. Mas a cidadania seria sempre vista como instrumento para equilibrar as desigualdades sociais e não para erradicá-las (TONET, 2012a, p. 64). 
Isto porque

a dimensão democrático/cidadã é, ao mesmo tempo, expressão e condição de reprodução da desigualdade social. O que significa que, por mais aperfeiçoada que seja a cidadania, ela jamais eliminará a desigualdade social, jamais permitirá aos indivíduos serem efetiva e plenamente livres (como expusemos anteriormente) (TONET, 2012b, p. 49. O parêntese é meu).

Em sua obra, Carvalho (2002) demonstra, com base no berço da sociabilidade capitalista moderna, a Inglaterra, que a cidadania e a democracia são traduzidas pelo exercício dos direitos civis, políticos e sociais dentro da plenitude historicamente possível, e que o não desenvolvimento e aperfeiçoamento constante desses direitos, seja pelas suspensões por períodos ditatoriais - ou mesmo por ingerência na vida político-econômica de alguns países por outros, retirando-lhes a soberania e ameaçando a autonomia do Estado-Nação, que não mais legisla em defesa de seus interesses endógenos, subsumindo-se aos exógenos -, ou por outros fatores que utilizem de expedientes semelhantes, acabam comprometendo as liberdades e direitos democráticos, gerando uma cidadania tipicamente inconclusa.

Ao que tudo indica, nas sociedades capitalistas modernas (alguns diriam pós-modernas) a cidadania e a democracia são vistas como o "teto da história", ou seja, o estágio mais avançado do progresso e desenvolvimento humanos, de modo que cabe, apenas, aperfeiçoá-las infinita e indefinidamente. Por isso, expõe Tonet (2012a, p. 64):

Para a esquerda democrática (...) não há uma articulação essencial entre cidadania e classes sociais e, portanto, entre cidadania e capitalismo. Segundo estes autores, na esteira de Aristóteles, o homem é um "animal político" por natureza. Isto significaria que a condição de cidadão é um elemento constitutivo da "condição humana". Sua forma concreta seria historicamente datada, mas a sua natureza essencial acompanharia a humanidade desde o começo até o fim. Argumenta-se, ainda, que a cidadania existiu antes do capitalismo, de modo que sua relação com ele seria apenas acidental e não essencial. Mais ainda: a história da construção da cidadania mostraria que esta é muito mais o resultado das lutas das classes trabalhadoras do que uma concessão da burguesia. Deste modo, a sua conquista plena seria um interesse daquelas classes e não da burguesia. Em última análise, a realização da cidadania plena se chocaria contra a lógica do capital, só sendo possível com a superação deste. Assim, a luta das classes subalternas não iria no sentido de superar a cidadania, mas de afastar as barreiras postas à sua plena realização.

A análise de Tonet reitera a afirmação já realizada e exige que explicitemos quais seriam as tarefas da democracia e da cidadania como meios - e não como fins - para a conquista da emancipação econômica como pressuposto da realização da emancipação humana.

\section{AS TAREFAS DA DEMOCRACIA E DA CIDADANIA}

Democracia e cidadania na sociedade capitalista (burguesa) correspondem à emancipação política, à igualdade jurídico-política, portanto, formal, abstrata entre os homens, como exposto anteriormente. Apesar, porém, do refreamento ao impulso revolucionário dado pela burguesia após a conquista efetiva do poder político, do Estado 
de Direito, passando a ser não mais uma classe revolucionária, mas sim conservadora, o que foi prontamente obliterado pela constituição da República Democrática (burguesa), essa primeira forma e momento de emancipação traz em seu bojo aspectos altamente vantajosos para a classe trabalhadora, caso tenha conhecimento dos seus limites e saiba como e o que fazer para superá-los. Deve-se atentar e enfatizar esse ponto, como fez Lênin, deixando claro o modo de enfrentamento e luta que devem ser travadas nesse momento do processo histórico-social.

Nós somos partidários da República Democrática como sendo a melhor forma de governo para o proletariado sob o regime capitalista, mas andaríamos mal se esquecêssemos que a escravidão assalariada é o quinhão do povo mesmo na república burguesa mais democrática. Todo Estado é uma força especial de repressão da classe oprimida. Um Estado, seja ele qual for, não poderá ser livre nem popular.

Não é essa República, de fato, que porá termo à dominação do capital nem, por conseguinte, à servidão das massas e à luta de classes; mas dará a essa luta uma profundidade, uma extensão, uma rudeza tais que, uma vez surgida a possibilidade de satisfazer os interesses essenciais das massas oprimidas, essa possibilidade se realizará fatalmente e unicamente pela ditadura do proletariado, arrastando consigo as massas.

(Entretanto, é necessário) desenvolver a democracia até o fim, procurar as formas desse desenvolvimento, submetê-las à prova da prática, etc., eis um dos problemas fundamentais da luta pela revolução social (LÊNIN, 1978, p. 24, 87-88, 96 . O parêntese é meu).

Conforme as palavras de Lênin, constatamos que a "república burguesa" está alicerçada na desigualdade socioeconômica entre os homens, ou seja, na "escravidão assalariada", embora o assalariado não mais se reconheça e identifique como um "escravo", o que pode ser atribuído, dentre outros fatores, à emancipação política, que torna todos os homens livres ("re"afirmando-os também como racionais), proprietários e iguais, assim como na "dialética do senhor e escravo" de Hegel:

na medida em que o escravo se torna consciente da sua condição de escravo, ele assume-se como tal e, portanto, liberta-se da escravidão porque deixa de servir ao seu senhor por obrigação e passa a servi-lo livremente. Logo, já não é mais escravo. $\mathrm{E}$, nesse mesmo ato, ele liberta também seu senhor da escravidão porque o senhor já não necessita exigir do escravo que o sirva sob coação, pois ele já o serve espontaneamente (SAVIANI, 2014, p. 88).

Apesar disso, por contradição, fazendo jus a sua própria etimologia - coisa pública, de todos, para todos -, também precisa ouvir e atender o povo, a classe trabaIhadora, senão dará margem a suspeitas, entreabrindo o perigo de questionamentos. Não podemos nunca esquecer, porém, que é uma "república estatal", e que um Estado, "seja ele qual for", jamais será "livre, nem popular", e sua forma legítima de atuação é também a força, a opressão, mesmo que prime pela busca do consenso a fim de obter a direção para sua dominação, evitando o uso desmedido e abusivo da força, fator geralmente desencadeador de desagradáveis efeitos colaterais que ameaçam a ordem, a coesão e o controle sobre o social. 
Ainda assim, pensando essa forma de governo e regime político republicano-democrático por contradição, enquanto "reconhecimento formal da igualdade entre os cidadãos, do direito igual para todos de determinar a força do Estado e de administrá-lo", decorre que, "num certo grau do seu desenvolvimento, a democracia unifica contra o capitalismo a classe revolucionária, o proletariado, fornecendo a este a possibilidade de quebrar a máquina do Estado burguês" (GRUPPI, 2001, p. 77-78). Desta feita, "desenvolvendo no grau máximo a democracia dentro do quadro do poder burguês, colocamos em crise a democracia burguesa. Isso porque, marchando para o pleno exercício da democracia" - estancado e passado ao controle da burguesia quando se estabelece no poder político e, de classe revolucionária passa a ser conservadora -, "percebemos que existe uma limitação, constituída pela propriedade privada dos meios de produção", evidenciando o "conteúdo de classe da democracia (burguesa)" (GRUPPI, 2001, p. 78-79. 0 parêntese é meu).

A democracia, ainda que burguesa, permite à classe trabalhadora utilizar taticamente as liberdades e direitos democráticos para fazer avançar a luta pelo comunismo, recrudescendo e radicalizando a luta pelas reformas ao exigir as reformas estruturais, impossíveis de serem executadas na forma social capital. Isto ocorre porque certas reivindicações e exigências, como a igualdade das condições materiais de existência (econômicas) para o desenvolvimento individual e diversificado de cada um, pressupõem mexer com questões estruturais que colocam em xeque a própria manutenção, sobrevivência e continuidade do sistema capitalista, como a propriedade privada e a desigualdade social, de modo que a exigência e concomitante impossibilidade de realização de certas reformas estruturais no sistema capital contribuem para o desvelamento e compreensão da premente necessidade da revolução social, elevando o nível de consciência das massas e denunciando "os limites da capacidade do capitalismo em se reformar" (TúMOLO, [2013?], p. 6).

Então, a luta de classes se acirra e tem o potencial de se tornar educativa, pedagógica, e a organização e mobilização racional, consciente e consequente da classe trabalhadora pode contribuir para que se torne classe dirigente, preparando as condições subjetivas, pela força de persuasão que essa classe assume perante os demais segmentos e ramos da produção social, contagiando todos os trabalhadores para a tomada objetiva do poder político, exercendo a sua dominação, na ditadura do proletariado:

em lugar de uma democracia para a minoria - que é uma ditadura sobre a maioria - temos uma democracia para a maioria com uma ditadura sobre a minoria. (...) Nessa democracia, todas as liberdades políticas burguesas são transformadas em realidade. Assim, essa liberdade se torna real, deixa de ser formal e válida somente para uma minoria de ricos (GRUPPI, 2001, p. 68).

Esse é apenas o início do processo de quebra do Estado para supressão e reabsorção/reassunção do poder do povo pelo povo, usurpado pelo Estado, transformando esse aparelho jurídico-político-ideológico-burocrático-militar em organizações comunais, autogeridas pelos próprios trabalhadores, desburocratizando, desmilitarizando e desjudicializando as atividades de administração da vida e produção/reprodução social. 
Para aniquilar o Estado é preciso transformar as funções do Estado em funções de fiscalização e registro tão simples que estejam ao alcance da enorme maioria da população e, em seguida, de toda a população. (...) Quando o Estado reduz as suas funções essenciais ao registro e ao controle dos próprios trabalhadores, deixa de ser Estado político (opressão de uma classe sobre outra) e as funções públicas, de políticas que eram, passam a ser simplesmente administrativas (LÊNIN, 1978, p. 96, 125).

A tomada do poder político e da atividade política pelos trabalhadores organizados é, tão somente, um meio para viabilizar, concretamente, o processo revolucionário, que, ao restituir o poder aos trabalhadores, o tornará um poder público, eliminando seu caráter político, isto é, "não será mais uma dominação sobre os homens, um poder estatal” (GRUPPI, 2001, p. 42).

(...) (A "ditadura do proletariado", em Marx,) não se refere a uma forma de Estado, mas a uma forma da relação entre as classes sociais num determinado momento, o da transição de um modo de produção a outro. O proletariado, após a quebra do poder político da burguesia, organizado em classe dominante, utilizará esse poder político não para manter a exploração do homem pelo homem, mas exatamente para aniquilar a resistência daquela classe à extinção dessa exploração (TONET, 2009, p. 10. O parêntese é meu).

Nessa direção também caminha Lukács (19--?), expondo as tarefas da "ditadura democrática", da "classe contra classe", alargando e forçosamente empurrando, obrigando a república a se democratizar radicalmente, cumprindo a agenda político-social que a burguesia nunca teve interesse de realizar, retomando os objetivos da "revolução democrática". "Na ditadura do proletariado, são levantados em primeiro lugar os objetivos democráticos e não os objetivos socialistas: a terra aos camponeses, a nacionalização dos bancos, e assim por diante" (GRUPPI, 2001, p. 95). Por isso mesmo, a revolução democrático-burguesa não é útil somente à burguesia; "ao mesmo tempo, ela é mais útil à classe operária do que à própria burguesia, pois permite à classe operária o exercício das liberdades democráticas, das quais ela precisa para a luta revolucionária" (GRUPPI, 2001, p. 77).

A ditadura do proletariado, diferentemente das demais revoluções ocorridas na história humana, como comprova a experiência da Comuna de Paris, de 1871, é uma "revolução política com alma social", ou seja, uma revolução que

não leva apenas a uma mudança na forma de exploração do homem pelo homem, mas à erradicação de toda exploração. Por isso mesmo ela deveria ser regida por uma forma de trabalho que levaria à extinção de todas as classes sociais e, portanto, de toda a desigualdade social (TONET, 2012c, p. 53).

Apesar do tempo transcorrido desde a Comuna de Paris, ela entra e marca a história das lutas e conquistas da classe trabalhadora, devendo servir como um referencial obrigatório para a formação e educação político-social das massas, sendo um clássico da luta de classes e, ainda mais, um dos raros momentos da história ${ }^{3}$ em que a classe

\footnotetext{
3 A revolução russa de 1917 inspira-se, em muitos aspectos, na experiência e lições da Comuna de Paris. O contexto e as circunstâncias, bem como a conjuntura histórico-social, porém, são outras, permitindo-nos, quando muito, aproximações, mas cuidadosamente refletidas e especificadas.
} 
trabalhadora desafia o poder de Estado do Direito burguês e o assalta, colocando em marcha um dos mais importantes aprendizados da classe trabalhadora a respeito da tomada do poder político. Como alerta Silva (2007, p. 52-54),

O que o proletariado tem de fazer é transformar o caráter capitalista daquele trabalho organizado e desses meios centralizados de trabalho, transformá-los de meios de dominação de classe e exploração de classe em formas de trabalho livre associado e meios sociais de produção.

\section{(...)}

Todo esse processo não pode transcorrer sob qualquer forma política. A transformação da estrutura política existente é uma precondição indispensável para iniciar a extirpação dos fundamentos econômicos da existência de classes. A Comuna foi "a forma política, finalmente descoberta, para levar a cabo a emancipação econômica do trabalho". Isso porque ela foi a "negação concreta" da "usurpação estatal": a reabsorção do poder de Estado pelos produtores reais através da organização das funções públicas (militares, administrativas, políticas) como funções subordinadas à autoridade autoconstituída dos produtores associados e exercidas pelos próprios produtores, em vez de por uma "casta treinada de parasitas do Estado" (funcionalismo público-estatal, trunfo da burocratização do capital aperfeiçoando sua dominação social). Com o "esmagamento" do Estado existente e a criação da forma política que é a sua "negação concreta", começa a supressão do Estado (apenas se iniciou, não tendo tempo, dentre outros fatores, de ser levada a cabo), que só pode ser completada no transcurso do trânsito ao comunismo, isto é, a uma forma societária capaz de auto-regulação puramente social, o que exige toda uma série de revolucionamentos orgânicos do modo de produção visando a extirpar os fundamentos econômicos da existência das classes (Os parênteses são meus).

Supera-se, assim, o limite egoístico da liberdade individual e da propriedade privada fundadas na desigualdade social, justamente pela realização da emancipação econômica do trabalho e do trabalhador, abolindo o trabalho assalariado, suprimido pelo trabalho associado, transformando o trabalhador em produtor, ou, como diz Marx, em "produtores livremente associados". A cisão entre indivíduo e cidadão e entre esfera privada e pública é superada e transcendida, reafirmando o homem como ser integral, retotalizando as dimensões manual e intelectual inerentes ao trabalho humano, o trabalho em geral, como frisa Marx em O Capital, também superando a divisão social-técnica-hierárquica do trabalho da sociabilidade capitalista. Uma outra forma de organização do trabalho é estabelecida, quando os produtores livremente associados controlam a universalidade do processo e dos meios de produção em todos os seus ramos e segmentos, exercendo um "domínio livre, consciente, coletivo e universal sobre o processo de produção e, a partir dele, sobre o conjunto do processo social" (TONET, 2009, p. 10)

Apenas nesses termos e como meios (instrumentos mediativos-organizativos), a democracia e a cidadania podem servir ao processo de transformação social radical da realidade humana, construindo as munições que abastecerão as armas para a luta a ser travada pela classe trabalhadora contra o capital. Para isso, deve-se constituir, legitimamente, como classe dirigente dos demais grupos e segmentos pertencentes à classe trabalhadora, e, portanto, atuar junto as massas, esclarecendo-as e explicando a lógica de funcionamento e de produção/reprodução da formação econômico-social capitalista, elevando o conhecimento cultural e moral das mesmas, pois não basta, nem 
adianta nada eu ficar sempre repetindo o refrão de que a sociedade é dividida em duas classes fundamentais, burguesia e proletariado, que a burguesia explora o proletariado e que quem é proletário está sendo explorado, se o que está sendo explorado não assimila os instrumentos pelos quais ele possa se organizar para se libertar dessa exploração (SAVIANI, 2007, p. 56).

Não é por outra razão que Gramsci insistia no trabalho educativo junto as massas para elevar sua consciência da imediaticidade cotidiana ao conhecimento científico-histórico-filosófico da realidade, auxiliando-as no processo de construção de uma concepção de mundo crítica, que unificasse teoria e prática, resultando numa nova cultura, na filosofia da práxis, promovendo uma reforma intelectual e moral que fortalecesse a hegemonia da classe trabalhadora para que, assim, fosse legitimado, de maneira consentida, o seu poder político-social. "O processo de hegemonia (dirigir, guiar, conduzir) é então um processo de unificação do pensamento e da ação" (GRUPPI, 2001, p. 100).

Dentre o patrimônio histórico-cultural acumulado pela humanidade, deve ser selecionado aquilo que há de mais elevado em termos históricos, filosóficos e artísticoculturais, voltados à promoção das necessidades, interesses e valores humano-sociais e genéricos e não aos interesses, necessidades e valores particulares e individualistas que são difundidos como representantes da vontade geral e do bem comum. Importa ressaltar, portanto, que não são quaisquer conteúdos, mas sim aqueles que podem munir a classe trabalhadora em sua luta contra o capital e os capitalistas e a capacite a ir além dos seus interesses e necessidades de classe, colocando-se em defesa dos interesses e necessidades do gênero humano, pois é a única classe capaz de ir além do capital, porque sua luta é para eliminar toda e qualquer forma de exploração do homem pelo homem, como também a propriedade privada, a desigualdade social e o Estado capitalista (Estado Político, de Direito, democrático - burguês).

Se os membros das camadas populares não dominam os conteúdos culturais, eles não podem fazer valer os seus interesses, porque ficam desarmados contra os dominadores, que se servem exatamente desses conteúdos culturais para legitimar e consolidar a sua dominação. (...) O dominado não se liberta se ele não vier a dominar aquilo que os dominantes dominam. Então, dominar o que os dominantes dominam é condição de libertação (SAVIANI, 2007, p. 55).

Vemos, assim, que a direção e a hegemonia da classe trabalhadora dependem da retotalização entre prática e teoria, entre "filosofia real" e "filosofia declarada", como aponta Gruppi (2001, p. 100-101), possível por meio da filosofia da práxis, da elevação do saber, do conhecimento de si e do mundo pelos homens, que passam a compreender a essência da aparência da sua forma social e histórica atual: o modo de produção capitalista, lutando para tomar o poder político a fim de destruí-lo, porque reabsorvido e reassumido pelos próprios homens, repondo a atividade produtiva de interação entre o homem e a natureza (o trabalho) como protoforma do ser social, rompendo e superando o fetiche da mercadoria e a alienação a ela inerente, retomando o controle sobre sua própria vida por intermédio do trabalho associado, quando todos os homens se transformam em trabalhadores e em produtores livremente associados. 


\section{À GUISA DE CONCLUSÃO: Possíveis Contribuições da Educação Escolar ao Processo de Transformação Social Radical}

O que cabe ao complexo social da educação, desvelados os limites e possibilidades da democracia e da cidadania? De antemão, sabemos que não é seu papel fazer a revolução social; essa é uma tarefa da classe trabalhadora organizada pelas lutas a serem travadas nos vários espaços sociais, abarcando os diversos setores e ramos da produção social. Então, qual sua função no processo de transformação social radical?

Podemos afirmar que uma de suas principais tarefas é deixar clara a sua própria natureza, pois, a partir daí, fica mais fácil compreender qual pode ser sua contribuição específica naquele processo. Saviani esclarece qual a função social, ou seja, a natureza da educação: "é o ato de produzir, direta e intencionalmente, em cada indivíduo singular, a humanidade que é produzida histórica e coletivamente pelo conjunto dos homens" (2008, p. 13), para que, assim, seja possível identificar os "elementos culturais que precisam ser assimilados pelos indivíduos da espécie humana para que eles se tornem humanos" (SAVIANI, 2008, p. 13), constituindo-os como membros do gênero humano.

\section{Ou, ainda, nas palavras de Tonet (2012b, p. 53):}

Apropriar-se do patrimônio genérico - conhecimentos, habilidades, valores - é condição imprescindível para que o indivíduo singular possa se transformar em membro efetivo do gênero humano. Esta é a tarefa essencial da educação. Neste sentido, formar o homem integral é permitir que ele tenha acesso, o mais pleno possível, ao conjunto de bens - materiais e espirituais - necessários a sua plena realização.

Se esta é a função social, a natureza essencial da educação, então, por desdobramento, uma de suas importantes contribuições está na capacidade de construir um conhecimento científico, histórico, filosófico do mundo, racionalmente sustentado, desvelando os nexos causais, as determinações reflexivas que demonstram aos homens as razões de viverem como vivem, que não são naturais, mas construtos sociais, e que, portanto, não só podem, como devem, interferir e transformá-las. Mesmo que não façam a história segundo sua vontade, ainda podem (re)produzi-la caso compreendam as condições e circunstâncias de sua formação. Afinal, as lutas sérias e consequentes e a transformação profunda da sociedade, demandam capacidade de compreensão e análise da realidade. Sendo assim, ainda que os homens não façam a história segundo sua vontade, é de exclusiva responsabilidade deles.

Podemos concluir, juntamente com Tonet (2012c, p. 62-63), que,

na educação, o foco deveria estar situado na realização de atividades educativas que contribuam para a formação de uma consciência revolucionária. Trata-se de nortear tanto a teoria como as práticas pedagógicas no sentido da emancipação humana e não no sentido do aperfeiçoamento da democracia e da cidadania (portanto, nada de "escola cidadã", construir uma "escola democrática", formar "cidadãos críticos"). Pois a questão é formar indivíduos que tenham consciência de que a solução para os problemas da humanidade está na superação da propriedade privada e do capital e na construção de uma forma comunista de sociabilidade. 
Certamente existe um patrimônio de saber acumulado, especialmente na área do conhecimento da natureza, mas, também na área do conhecimento específico do ser social, para cujo acesso universal deve-se lutar. Todavia, não se pode esquecer que mesmo o acesso a esse patrimônio é organizado, independente de intencionalidade direta, de modo a atender os interesses da burguesia (O parêntese é meu).

Isto porque, sob a regência do capital, a educação

sempre será desigualitária, mesmo nas suas formas mais aperfeiçoadas. Além disso, ela sempre será hegemonizada pelas classes dominantes, em seus conteúdos e em suas formas, o que significa que a tônica nunca irá no sentido de contribuir para formar indivíduos integrados à luta pela construção de uma autêntica comunidade humana. Exatamente porque isto significa formar pessoas para mudar radicalmente esta ordem social (TONET, 2012b, p. 55-56).

Logo, podemos afirmar que

não se trata de lutar apenas pelo acesso universal ao patrimônio acumulado do saber. Para além disso, é preciso fazer a crítica desse saber e permitir a aquisição de um conhecimento de caráter revolucionário. Desnecessário dizer que a figura do professor é, aqui, de suma importância, pois depende dele imprimir à sua atividade educativa esse caráter (TONET, 2012c, p. 63).

Diante disso, o que pressupõe, diga-se de passagem, é um domínio histórico, científico e filosófico da realidade pelo professor na perspectiva do trabalho (como protoforma do ser social) e da classe trabalhadora, reconhecendo-se como pertencente a essa classe para, a partir daí, transcender seus interesses e necessidades de classe, como expusemos anteriormente, podendo, assim, se colocar em prol dos interesses, necessidades e valores humano-sociais e genéricos, lembrando, como faz questão de enfatizar Tonet (2012c, p. 63), que "não se trata de doutrinar - fazer acreditar baseado na autoridade -, mas de permitir o acesso a um conhecimento racionalmente sustentado." Desta feita, "por outro lado, esse conhecimento, pela sua própria natureza, será um poderoso estímulo para o engajamento nas lutas práticas, tanto aquelas particulares como aquelas mais gerais".

Concluindo, queremos ressaltar que não é nosso objetivo jogar toda a responsabilidade aos professores, sobrecarregando-os e exigindo que sejam "super-homens". Apenas destacamos que, como acompanhantes e condutores, como formadores e educadores das massas, precisam se colocar à altura dessa função, tendo plena ciência de que não há neutralidade na produção científica e que é justamente o posicionamento de classe que torna o conteúdo conservador ou revolucionário, possibilitando a capacidade de discernir quais deles, em suas correlatas perspectivas e concepções de mundo, permitem um conhecimento mais aproximado e verdadeiro da realidade. Como afirmar Tonet (2013, p. 111), "desde que assumida a perspectiva da classe que, naquele momento histórico, fundamenta o padrão cognitivo mais elevado possível, a tomada de partido se revela uma condição positiva e imprescindível para a elaboração do conhecimento científico". 


\section{REFERÊNCIAS}

CARVALHO, José Murilo de. Cidadania no Brasil: o longo caminho. 3. ed. Rio de Janeiro: Civilização Brasileira, 2002.

ENGELS, Friedrich. A origem da família, da propriedade privada e do Estado. Trad. Leandro Konder. 9. ed. Rio de Janeiro: Civilização Brasileira, 1984.

GRUPPI, Luciano. Tudo começou com Maquiavel - as concepções de Estado em Marx, Engels, Lênin e Gramsci. 16. ed. Porto Alegre: L\&PM Editores, 2001.

IASI, Mauro Luis. "O conceito e o 'não conceito' de classes em Marx". In: IASI, Mauro Luis. Ensaios sobre consciência e emancipação. 2. ed. São Paulo: Expressão Popular, 2011.

LÊNIN, Vladimir I. O Estado e a revolução. São Paulo: Hucitec, 1978.

LOCKE, John. Segundo Tratado sobre o governo. São Paulo: Ed. Martin Claret, 2002.

LUKÁCS, George. As teses de Blum - extrato: a ditadura democrática. [S.I.]: [s.n.], (19--?). Disponível em: <https://www.marxists.org/portugues/lukacs/1928/mes/teses.htm>.

MARX, Karl. A questão judaica. Rio de Janeiro: Achiamé, [1989?].

SAVIANI, Dermeval. Escola e democracia: teoria da educação, curvatura da vara, onze teses sobre a educação política. 39. ed. Campinas, SP: Autores Associados, 2007. (Coleção Polêmicas do Nosso Tempo, v. 5).

. O lunar de Sepé - paixão, dilemas e perspectivas na educação. Campinas, SP: Autores Associados, 2014. (Coleção educação contemporânea).

. Pedagogia histórico-crítica - primeiras aproximações. 10. ed. rev. Campinas, SP: Autores Associados, 2008. (Coleção educação contemporânea).

SILVA, Rafael Afonso da. Dilemas da transição: um estudo crítico da obra de Lênin de 1917-1923. 2007. Dissertação (Mestrado em Ciências Sociais) - Universidade Estadual de Campinas, Instituto de Filosofia e Ciências Humanas, Campinas, São Paulo, 2007.

TONET, Ivo. Educar para a cidadania ou para a liberdade? In: TONET, Ivo. Educação contra o capital. 2. ed. rev. São Paulo: Instituto Lukács, 2012a.

Educação e cidadania. In: TONET, Ivo. Educação contra o capital. 2. ed. rev. São Paulo: Instituto Lukács, 2012b.

Educação e revolução. In: BERTOLDO, Edna; MOREIRA, Luciano Accioly Lemos; JIMENEZ, Susana (Org.). Trabalho, educação e formação humana frente à necessidade histórica da revolução. São Paulo: Instituto Lukács, 2012c.

Marxismo e democracia. In: BORGES, L. F. P.; MAZZUCO, N. C. (Org.). Democracia e políticas sociais na América Latina. São Paulo: Xamã, 2009. Disponível em: <http://www.ivotonet.xpg.com.br/>.

Método científico: uma abordagem ontológica. São Paulo: Instituto Lukács, 2013.

TÚMOLO, Paulo Sérgio. Educação dos trabalhadores, consciência de classe e revolução social - a atualidade de "velhas" questões. [2013?]. Disponível em: <www.estudosdotrabalho.org>. 